\title{
Autoradiographic Estimation of Competence and the Relationship between Competence and Transformability in Cultures of Bacillus subtilis
}

\author{
By C. A. VERMEULEN AND G. VENEMA \\ Genetical Institute, University of Groningen, Kerklaan 30, \\ Haren (Gn), The Netherlands
}

(Accepted for publication 27 August 1971)

\begin{abstract}
SUMMARY
The size of the competent fraction in Bacillus subtilis cultures was calculated from the frequencies of observed and expected double transformants for the two unlinked markers adenine and indole, and compared with that obtained by lightmicroscopic autoradiography of samples exposed to $\left[{ }^{3} \mathrm{H}\right]$ thymidine labelled donor DNA. The two methods give similar results. The size of the competent fraction calculated from the frequencies of observed and expected double transformants is independent of the concentration of DNA and time of exposure to transforming DNA. The observed increase in the frequency of transformation with longer periods of exposure of the cultures to DNA was found to be linearly correlated with the amounts of DNA taken up by individual cells, as judged by the number of grains per labelled cell. No important heterogeneity within the competent fraction with respect to the amount of DNA absorbed per competent cell was observed. It was further demonstrated that under conditions in which competence develops (the competence regime), the transformation frequency and the size of the competent fraction increase proportionally, whereas the amount of DNA absorbed per competent cell does not change. This suggests that the efficiency of competent cells to integrate the donor markers is constant during the competence regime, and is, therefore, not a significant factor determining changes in transformability.
\end{abstract}

\section{INTRODUCTION}

Bacterial transformation can be defined as the ability of certain bacterial strains to absorb DNA extracted from a genetically related strain (the donor), to integrate this into their genome and to express the donor character. Competence is defined as the ability to bind or to take up DNA. It is clear that competence is directly related to transformability; however, it should be kept in mind that the level of transformation is, in principle, not only dependent on the size of the competent fraction. A further factor which might contribute to transformability is the efficiency of the cells to integrate the donor DNA and to express the donor phenotype. Several years ago, Goodgal \& Herriott (I96r) developed a method for estimating the size of the competent fraction. This method is based upon the statistical rule, that the chance of two independent events occurring simultaneously equals the product of the chances of each event occurring separately. Application of this rule to calculate the size of the competent fraction means, in practice, that after exposure to prototrophic DNA the frequency of double transformants of a strain carrying two unlinked markers is determined and compared with the expected frequency which is obtained by multiplication of the frequencies of single transformants. The disparity between the observed and expected frequencies is a direct measure of the size of the competent fraction. The theory is restricted 
to uninuclear cells and is only applicable if the two segments of donor DNA are integrated independently (Nester \& Stocker, 1963; Hadden \& Nester, 1968). Cahn \& Fox (I968) who have recently reconsidered Goodgal and Herriott's method, have suggested that the size of the competent fraction as estimated according to that method should be divided by a factor of two since only half of the number of potential double transformants is scored as actual double transformants if, with single strand integration, either of the two DNA strands is equally efficient in transformation. There is at present no evidence contradictory to the assumption that in Bacillus subtilis integration occurs at the single stranded level (Bodmer \& Ganesan, 1964; Venema, Pritchard \& Venema-Schröder, 1965; Vestri, Felicetti \& Lostia, I966; Dubnau \& Davidoff-Abelson, I971). One of the objectives of the present study was to examine how the size of the competent fraction calculated according to Goodgal and Herriott's method without the modification suggested by Cahn \& Fox (1968) is related to that obtained by light-microscopic autoradiography of competent cultures exposed to $\left[{ }^{3} \mathrm{H}\right]$ thymidine labelled donor DNA. In addition, since no direct evidence has been furnished whether variations in transformability between different cultures, and the increase in transformability as a function of time of growth in a given medium (the competence regime) are due to variations in the size of the competent fraction, or to changes in the capacity of competent cells to incorporate and to integrate donor DNA, attention was also given to these aspects, again by making use of light-microscopic autoradiography. Finally, the autoradiographic method allowed us to examine the question whether there exists variation in the DNA absorption capacity of cells in a competent culture.

\section{Bacterial strains}

METHODS

A nonsporulating strain of Bacillus subtilis $\mathrm{I} 68$ ade $\operatorname{trpC2}$ requiring adenine and indole ( $\mathrm{Ade}^{-} \mathrm{Ind}^{-}$) was used as recipient. This strain was derived from the $\operatorname{trp} C 2$ mutant by mutation with $N$-methyl- $N^{\prime}$-nitro- $N$-nitroso guanidine (50 $\mu \mathrm{g} . / \mathrm{ml}$.). Donor DNA was isolated either from wild-type 168 or from strain 168 requiring thymine and tyrosine (Thy- $\mathrm{Tyr}^{-}$), unless stated otherwise.

\section{Competence regime}

Cells from colonies grown on agar plates were inoculated in Spizizens's (1958) minimal medium, supplemented with glucose $(0.5 \%)$, casein hydrolysate $(0.02 \%)$, and the appropriate growth requirements $\left(20 \mu \mathrm{g} . / \mathrm{ml}\right.$.) and grown overnight at $37^{\circ}$. Cultures were grown to maximal competence by either one of the following two methods.

Method A. Overnight cultures were diluted approximately fivefold with fresh medium (optical density after dilution approximately 0.5 at $450 \mu$ ) and grown for 2.5 to $3 \mathrm{~h}$. at $37^{\circ}$ with mild aeration until the increase in optical density was only half of the value obtained during logarithmic growth. Cultures were then diluted twofold with fresh medium without casein hydrolysate and the growth requirements and grown for $2.5 \mathrm{~h}$. at $37^{\circ}$ with vigorous aeration.

Method B. Overnight cultures were centrifuged and resuspended in seven vol. fresh medium (optical density after dilution approximately 0.5 at $450 \mu$ ) without casein hydrolysate but supplemented with $\mathrm{Mg} \mathrm{SO}_{4}\left(7.5 \times 10^{-3} \%\right)$, the growth requirements $(20 \mu \mathrm{g} . / \mathrm{ml}$.) and the competence enhancing amino acids $(50 \mu \mathrm{g}$. $/ \mathrm{ml}$.) advised by Wilson \& Bott (1968). Cultures were grown for 3 to $3.5 \mathrm{~h}$. at $37^{\circ}$ with mild aeration until the increase in optical density was only half of the value obtained during logarithmic growth, diluted twofold with 
fresh Spizizen's minimal medium supplemented with glucose $(0.5 \%)$ only, and grown $90 \mathrm{~min}$. at $37^{\circ}$ with vigorous aeration.

\section{DNA preparation}

Non-radioactive DNA was prepared from overnight cultures of wild-type cells; DNA labelled with $\left[{ }^{3} \mathrm{H}\right]$ thymidine was isolated from $\mathrm{Thy}^{-} \mathrm{Tyr}^{-}$cells grown in the following way: overnight cultures were diluted a hundredfold with fresh medium supplemented with tyrosine $(20 \mu \mathrm{g} . / \mathrm{ml}$. $)$ and $\left[{ }^{3} \mathrm{H}\right]$ thymidine $\left(3 \mu \mathrm{g} . / \mathrm{ml}\right.$, , methyl-T, specific activity ${ }_{3} \mathrm{C} / \mathrm{mmole}$, Radiochemical Centre, Amersham, Buckinghamshire). After subsequent incubation for I 2 to $20 \mathrm{~h}$. at $37^{\circ}$ with mild aeration the cells were either collected by centrifugation or by filtration on membrane filters (type HA pore size $0.45 \mu$, Millipore Corp., Bedford, Massachusetts, U.S.A.) and washed three times with io vol. fresh medium supplemented with cold thymidine $(50 \mu \mathrm{g} . / \mathrm{ml}$.) and tyrosine $(20 \mu \mathrm{g} . / \mathrm{ml}$.). Both radioactive and non-radioactive DNA were isolated according to the method described by Venema et al. (1965), simplified to the extent that after the first precipitation with 2-ethoxyethanol and redissolving the DNA in standard saline citrate (SSC; $0.15 \mathrm{M}-\mathrm{NaCl}+0.015 \mathrm{M}$-sodium citrate) no further purification was attempted. The DNA solution was dialysed for 2 to 3 days at $4^{\circ}$ against 3 to 41 . changes of SSC. DNA concentrations were estimated photometrically by the method of Dische-Burton (Burton, 1956). The preparation was stored in $\mathrm{I} \cdot 5 \mathrm{M}-\mathrm{NaCl}$ at $4^{\circ}$.

\section{Transformation procedure}

Samples of recipient cultures were incubated with donor DNA at $37^{\circ}$ and gently aerated, DNA uptake was terminated by further incubation for at least $5 \mathrm{~min}$. with bovine pancreatic deoxyribonuclease (DNase; $20 \mu \mathrm{g}$. $/ \mathrm{ml}$., BDH) in the presence of $0.03 \mathrm{M}-\mathrm{MgSO}_{4}$. Viable counts and transformation frequencies were determined by plating on minimal agar supplemented with casein hydrolysate $(0.02 \%)$ and the appropriate growth requirements.

\section{Light-microscopic autoradiography}

One ml. samples were exposed to approximately saturating concentrations of ${ }^{3} \mathrm{H}$-labelled DNA and washed three times with Io vol. fresh medium supplemented with cold thymidine $(80 \mu \mathrm{g} . / \mathrm{ml}$.) and $20 \mu \mathrm{g} . / \mathrm{ml}$. of adenine, indole and tyrosine. Samples $(0.05 \mathrm{ml}$.) were spread on microscope slides, dried at room temperature, stained with $\mathrm{I} \%$ crystal violet in distilled water for 5 min.; rinsed with tap water, absolute alcohol, distilled water and dried at room temperature. Slides were coated with Kodak AR-Io stripping film (Kodak Ltd) as described by Rogers (1967), dried at room temperature and stored at $4^{\circ}$ in light-tight boxes containing silica gel. After exposure, the edges of the film were coated with nailpolish to prevent the film from floating off and the slides were developed in Kodak Digb developer for $5 \mathrm{~min}$. at $18^{\circ}$, rinsed in tap water, fixed in $\mathrm{Na}_{2} \mathrm{~S}_{2} \mathrm{O}_{3}\left(25 \%\right.$, w/v) and $\mathrm{K}_{2} \mathrm{~S}_{2} \mathrm{O}_{5}(2.5 \%$, w/v) for $5 \mathrm{~min}$., rinsed in tap water for $5 \mathrm{~min}$. and finally dried at room temperature. Slides were examined with a Zeiss microscope at a magnification of $1000 ; 2000$ to 5000 cells per sample were scored for grains. Background labelling was determined by counting the number of labelled cells and the number of grains per cell in autoradiographs of cells not exposed to radioactive DNA. The number of background grains per cell was used to correct the number of grains per cell in the experimental samples, on the assumption that the distribution of background grains in the experimental and control samples are similar. 


\section{Determination of radioactivity}

Radioactivity of DNA preparations was determined in a Nuclear-Chicago liquid scintillation counter using Bray's solution (Bray, 1960).

\section{RESULTS}

Linkage between the ade and trpC2 loci. Since Goodgal and Herriott's method for estimating the size of the competence fraction can only be used if the relevant markers are not linked, it had first of all to be established whether the newly introduced mutation, resulting in adenine deficiency, was linked to the $\operatorname{trp} C 2$ locus or not. Figure I shows the relationship

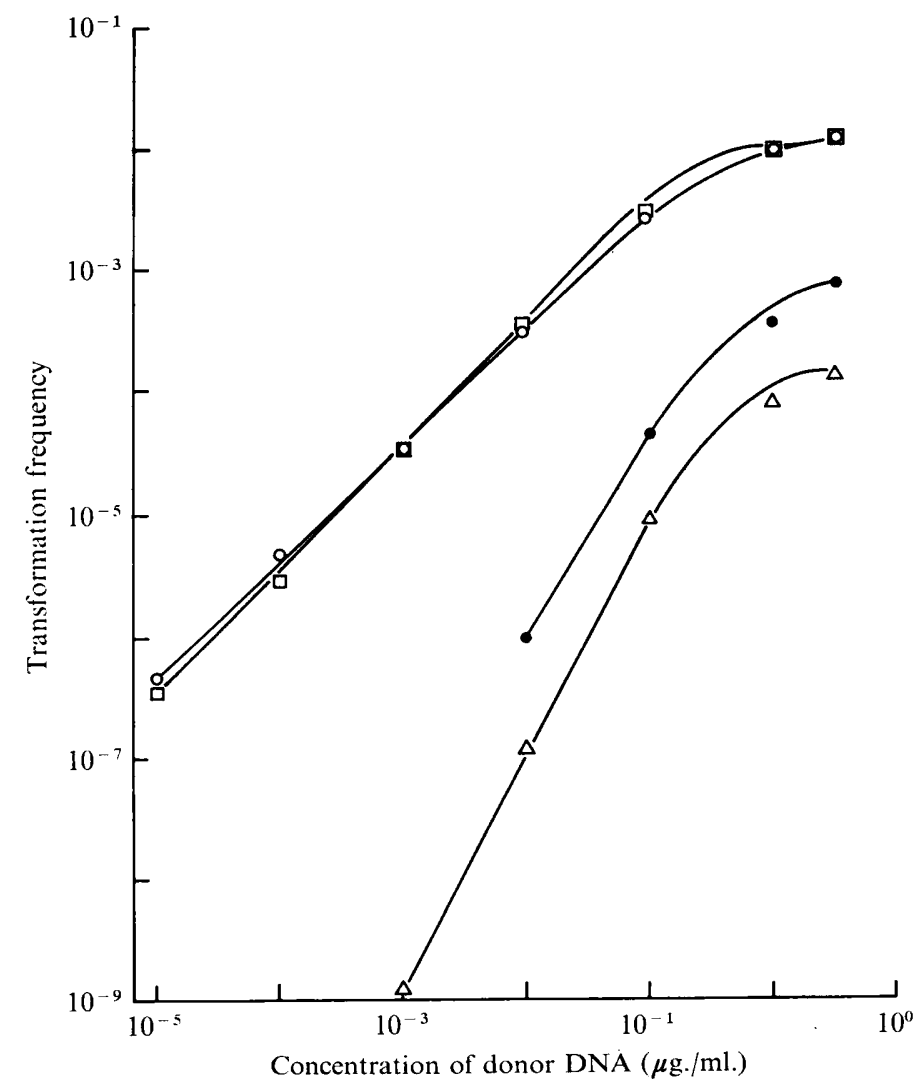

Fig. I. Relation between the concentration of DNA and the frequency of $\mathrm{Ade}^{+}$, Ind $\mathrm{In}^{+}$and $\mathrm{Ade}^{+}$Ind ${ }^{+}$double transformants. Samples grown to maximum competence (method A) were exposed to various concentrations of wild-type DNA for $30 \mathrm{~min}$. at $37^{\circ}$, treated with DNase $(50 \mu \mathrm{g} / \mathrm{ml})$ for 5 min. and plated. $O-O$, Ade transformants; $\square-\square$, Ind ${ }^{+}$transformants; - , Ade $^{+}$Ind $^{+}$ double transformants; $\triangle-\triangle$, expected $\mathrm{Ade}^{+}$Ind $^{+}$double transformants for unlinked loci.

between DNA concentration and the frequencies of single and double transformants, together with the expected frequencies of double transformants if the markers were not linked. From the agreement between the slopes of the experimental and the predicted curve it is concluded that the ade and $\operatorname{trp} C 2$ loci are not linked. The high numbers of double transformants as compared with the expected numbers indicate that only part of the culture was competent. 
Effect of DNA concentration and the time of exposure to DNA on the size of the competent fraction. Table I shows the effect of DNA concentration during transformation on the size of the competent fraction, as estimated from the frequencies of observed and expected double transformants. The size of the competent fraction turns out to be independent of the amount of DNA used. These results are in agreement with those presented by others (Nester \& Stocker, 1963; Riva \& Polsinelli, 1968; Singh \& Pitale, 1968). Table 2 shows the effect of various periods of incubation with DNA on the estimated size of the competent fraction. In order to detect possible changes in the size of the competent fraction within a $60 \mathrm{~min}$. period of exposure, cells were also exposed to transforming DNA during the latter half of this period. Although there is some variation, there is no evidence that the length of the incubation period with DNA affects the calculated size of the competent fraction.

\section{Table I. Effect of DNA concentration on the size of the competent fraction}

Cultures were grown to maximum competence according to method $\mathrm{A}$, exposed to various amounts of prototrophic DNA for $30 \mathrm{~min}$., treated with DNase and plated. Results are mean values of three experiments.

\begin{tabular}{|c|c|}
\hline $\begin{array}{c}\text { DNA } \\
\text { concentration } \\
(\mu \mathrm{g} . / \mathrm{ml} .)\end{array}$ & $\begin{array}{l}\text { Size of the } \\
\text { competent } \\
\text { fraction }(\%)\end{array}$ \\
\hline $\begin{array}{l}10^{-5} \\
10^{-4} \\
10^{-3}\end{array}$ & $\begin{array}{l}\text { No doubles } \\
\text { scored }\end{array}$ \\
\hline $10^{-2}$ & $16.0 \pm 5.9$ \\
\hline $10^{-1}$ & $20.5 \pm 10$ \\
\hline I & $22 \cdot 2 \pm 8 \cdot 9$ \\
\hline 3 & $12.4 \pm 4.5$ \\
\hline
\end{tabular}

Table 2. Effect of the period of exposure to DNA on the size of the competent fraction

Cultures were grown to maximum competence according to method $\mathbf{A}$, exposed to prototrophic DNA $(3 \mu \mathrm{g} . / \mathrm{ml}$.) for various periods of time, treated with DNase and plated. Results are mean values of four experiments.

$\begin{array}{cc}\begin{array}{c}\text { Time of } \\ \text { exposure to } \\ \text { DNA (min.) }\end{array} & \begin{array}{c}\text { Size of the } \\ \text { competent } \\ \text { fraction (\%) }\end{array} \\ 0-1 & \text { (No doubles scored) } \\ 0-2 \cdot 5 & \text { (No doubles scored) } \\ 0-5 & 14 \cdot 8 \pm 3 \cdot 8 \\ 0-7 \cdot 5 & 13 \cdot 9 \pm 4 \cdot 2 \\ 0-10 & 15 \cdot 1 \pm 7 \cdot 2 \\ 0-15 & 11.9 \pm 2.4 \\ 0-30 & 22 \cdot 5 \pm 7 \cdot 5 \\ 0-45 & 21 \cdot 1 \pm 8 \cdot 2 \\ 0-60 & 16 \cdot 7 \pm 5 \cdot 9 \\ 30-60 & 17 \cdot 3 \pm 3 \cdot 7\end{array}$

Comparison between the size of the competent fraction determined by autoradiography and that calculated according to Goodgal and Herriott's method. When competent cultures are exposed to ${ }^{3} \mathrm{H}$ DNA and autoradiographs are made, relevant data on the size of the competent fraction can only be obtained if those cells which have absorbed donor DNA irreversibly give rise to autoradiographically identifiable cells. If it is assumed that the number of grains is randomly distributed over competent cells, the fraction of cells which have incorporated DNA, but do not show as labelled cells can be estimated by applying the first term $n / \mathrm{e}^{-u}$ of the Poisson distribution in which $n$ represents the number of labelled cells and 
$u$ the average number of grains per labelled cell. The interval between coating with photographic emulsion and the development of the autoradiographs was chosen in such a way that the average number of grains per labelled cell was at least three. It follows from the Poisson distribution that $5 \%$ of cells which have incorporated ${ }^{3} \mathrm{H}$ DNA will not be registered autoradiographically if the average number of grains per labelled cell is three. The results of the comparison between Goodgal and Herriott's method and the autoradiographic method are presented in Table 3 from which three conclusions can be drawn. (I) The agreement between the autoradiographic results and those obtained by Goodgal and

\section{Table 3. Comparison between the size of the competent fraction calculated according to Goodgal and Herriott's methoa and that determined by autoradiography}

Cultures were grown to maximum competence either according to method A or method B and exposed to prototrophic DNA $\left(3 \mu \mathrm{g} . / \mathrm{ml}\right.$.) or ${ }^{3} \mathrm{H}$ labelled (specific activity approximately $3 \times 10^{5}$ d.p.m. $/ \mu$ g.). Samples exposed to prototrophic DNA were plated for the estimation of the size of the competent fraction by transformation. Samples exposed to ${ }^{3} \mathbf{H}$ labelled DNA were washed by centrifugation and autoradiographed.

\begin{tabular}{|c|c|c|c|c|c|c|c|c|c|}
\hline \multirow{3}{*}{$\begin{array}{l}\text { Expt } \\
\text { no. }\end{array}$} & \multirow{3}{*}{$\begin{array}{l}\text { Compe- } \\
\text { tence } \\
\text { regime }\end{array}$} & \multirow{3}{*}{$\begin{array}{l}\text { Incuba- } \\
\text { tion } \\
\text { period } \\
\text { (min.) }\end{array}$} & \multirow{2}{*}{\multicolumn{3}{|c|}{$\begin{array}{c}\text { Transformation } \\
\text { frequency } \times 10^{-2}(\%)\end{array}$}} & \multirow{3}{*}{\multicolumn{2}{|c|}{ 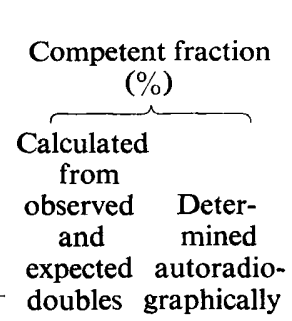 }} & \multirow{3}{*}{$\begin{array}{l}\text { Average no. of } \\
\text { grains/labelled } \\
\text { cell }\end{array}$} & \multirow{3}{*}{$\begin{array}{c}\text { Average } \\
\text { no. of } \\
\text { grains/ } \\
\text { labelled } \\
\text { cell } \\
\text { extra- } \\
\text { polated } \\
\text { for } \\
3 \text { weeks of } \\
\text { exposure }\end{array}$} \\
\hline & & & & & & & & & \\
\hline & & & $\mathrm{Ade}^{+}$ & Ind $^{+}$ & $\mathrm{Ade}^{+}$Ind $^{+}$ & & & & \\
\hline I & A & 30 & 147 & 103 & $5 \cdot 8$ & $26 \cdot 2$ & $27 \cdot 9$ & $4 \cdot I / 2$ I days & $4 \cdot I$ \\
\hline 2 & A & 30 & 33 & 16 & 0.5 & $10 \cdot 7$ & $7 \cdot I$ & $4 \cdot 3 / 20$ days & $4 \cdot 5$ \\
\hline 3 & B & 10 & 133 & $8 I$ & $5 \cdot 63$ & $16 \cdot 3$ & I $2 \cdot 8$ & $3 \cdot 6 / 60$ days & $I \cdot 3$ \\
\hline 3 & B & 30 & 225 & I95 & $28 \cdot 6$ & $15 \cdot 3$ & $15 \cdot 1$ & $3 \cdot 8 / 32$ days & $2 \cdot 5$ \\
\hline Aver & rage & & & & & I $7 \cdot I$ & $15 \cdot 7$ & & \\
\hline
\end{tabular}

Table 4. Effect of the period of exposure to DNA on the frequencies of transformed and labelled cells and the average number of grains per labelled cell

Cultures were grown to maximum competence (method A) and exposed to prototrophic DNA $\left(3 \mu \mathrm{g} . / \mathrm{ml}\right.$.) or ${ }^{3} \mathrm{H}$ labelledDNA (specific activity approximately $3 \times 10^{5} \mathrm{~d} . \mathrm{p} . \mathrm{m}$. $/ \mu \mathrm{g}$.). Samples exposed to prototrophic DNA were plated for assaying the transformation frequencies, whereas samples exposed to ${ }^{3} \mathrm{H}$ labelled DNA were washed by centrifugation and autoradiographed.

$\begin{array}{ccc}\begin{array}{c}\text { Incubation } \\ \text { period } \\ \text { (min.) }\end{array} & \begin{array}{c}\text { Transformation } \\ \text { frequency to } \\ \text { Ade }^{+} \times 10^{-2}(\%)\end{array} & \begin{array}{c}\text { Frequency of } \\ \text { labelled cells } \\ (\%)\end{array} \\ 5 & 9.6 & 13.8 \\ 10 & 50 & 13.9 \\ 30 & 109 & 16.9\end{array}$

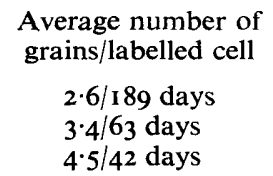

Average number of grains/labelled cell extrapolated for 3 weeks of exposure

0.3

$\mathbf{I} \cdot \mathbf{I}$

$2 \cdot 5$

Herriott's method is reasonable, although the size of the competent fraction determined by autoradiography is usually somewhat smaller. (2) The cells in cultures grown by the same method but differing considerably in transformability (Table 3, Expt I, 2) incorporate approximately the same amount of DNA from the medium; the difference in transformability is largely due to the difference in the size of the competent fraction of these cultures. Comparison between the results of Expt $I$ and 2 and the second of Expt 3 (Table 3) indicates that cells of competence regime $\mathrm{B}$, to which the stimulatory amino acids were added 
(Wilson \& Bott, 1968), yield substantially more transformants per unit of DNA added to the recipient culture. Whether this is due to a higher efficiency to integrate and/or express the donor character, or to increased absorption of DNA per competent cell cannot be decided, since the exact amounts of labelled DNA added to the cultures subjected to competence regime A and B have not been measured. (3) The period of exposure to DNA has no significant effect on the frequencies of labelled cells as indicated by the results of Expt 3 . Since, with increasing time of exposure to DNA the transformation frequencies and the average number of grains per labelled cell increase almost proportionally (Expt 3, Table 3, 4), it may be concluded that the increase in transformation frequency is primarily due to an increased uptake of transforming DNA per competent cell. The data do not permit us to exclude the possibility that a small part of the increase in transformation frequency with increasing periods of exposure to DNA is due to cells which have become competent during the period of exposure.
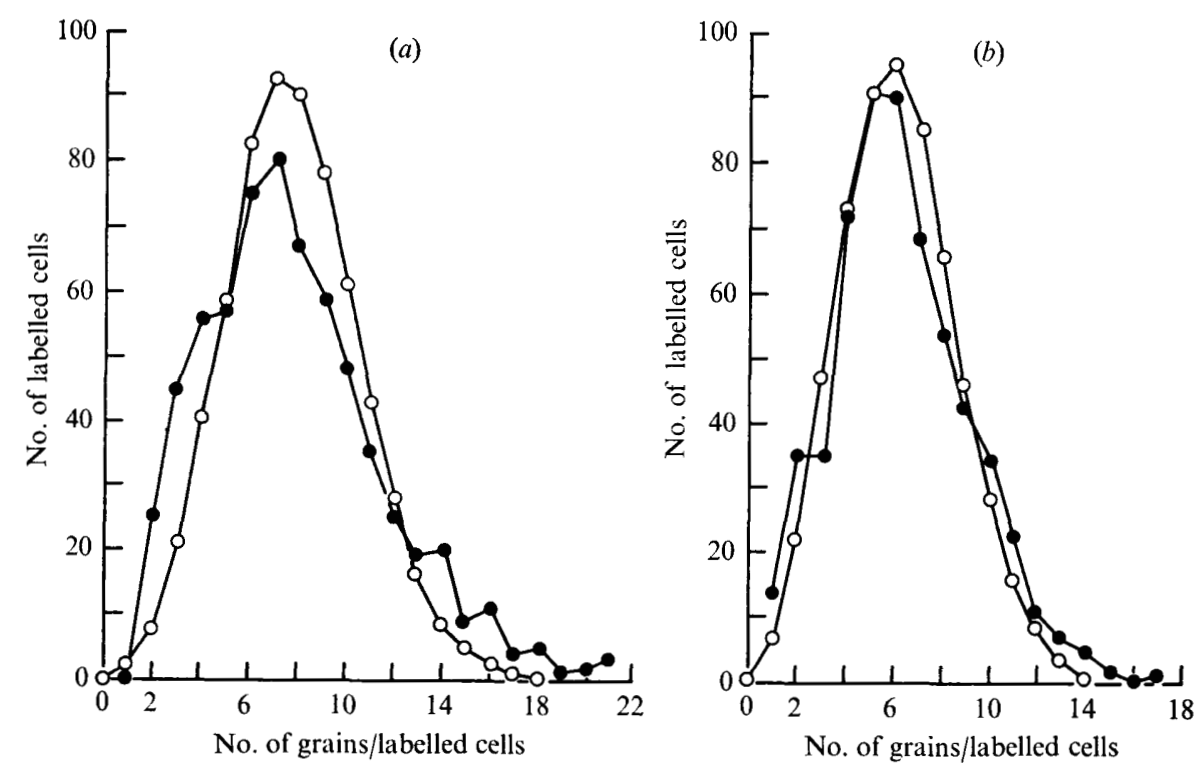

Fig. 2. Distribution of the number of grains over labelled cells. Cultures grown to maximum competence (method A) were exposed to ${ }^{3} \mathrm{H}$ labelled DNA (specific activity approximately $3 \times 10^{5}$ d.p.m. $/ \mu \mathrm{g}$.) for $30 \mathrm{~min}$. at $37^{\circ}$, treated with DNase $(50 \mu \mathrm{g} . / \mathrm{ml}$.), washed by centrifugation and autoradiographed. $(a)$ and $(b)$. Duplicate experiments. -0 , observed grain number distribution; $\mathrm{O}-\mathrm{O}$, Poisson distribution.

Cellular variation in the amount of irreversibly fixed DNA. As can be seen from Fig. $2 a$ and $b$, the grain number distribution fit a Poisson distribution fairly well. These results suggest: (i) that the majority of the competent cells are uniform with respect to their DNA absorption capacity, if it is assumed that disintegration of tritium follows a Poisson distribution and (ii) that the large majority of competent cells keep their competence for at least $30 \mathrm{~min}$.

However, there is usually some displacement in the grain number distribution towards lower grain numbers per labelled cell, indicating perhaps, that during the period of exposure to DNA, a small number of cells has become competent, but has not been able to incorporate the maximally possible amount of DNA before addition of DNase or, alternatively, has lost its competence before the addition of DNase. 
The second conclusion drawn from the grain number distributions needs some explanation. If during the $30 \mathrm{~min}$. incubation period with DNA a considerable fraction of the competent population had lost its competence and noncompetent cells had become competent, one would expect that the distribution of the number of grains per labelled cell would deviate considerably from the Poisson distribution. In order to test the second conclusion more directly, the duration of the competence of individual cells was estimated in the following way.

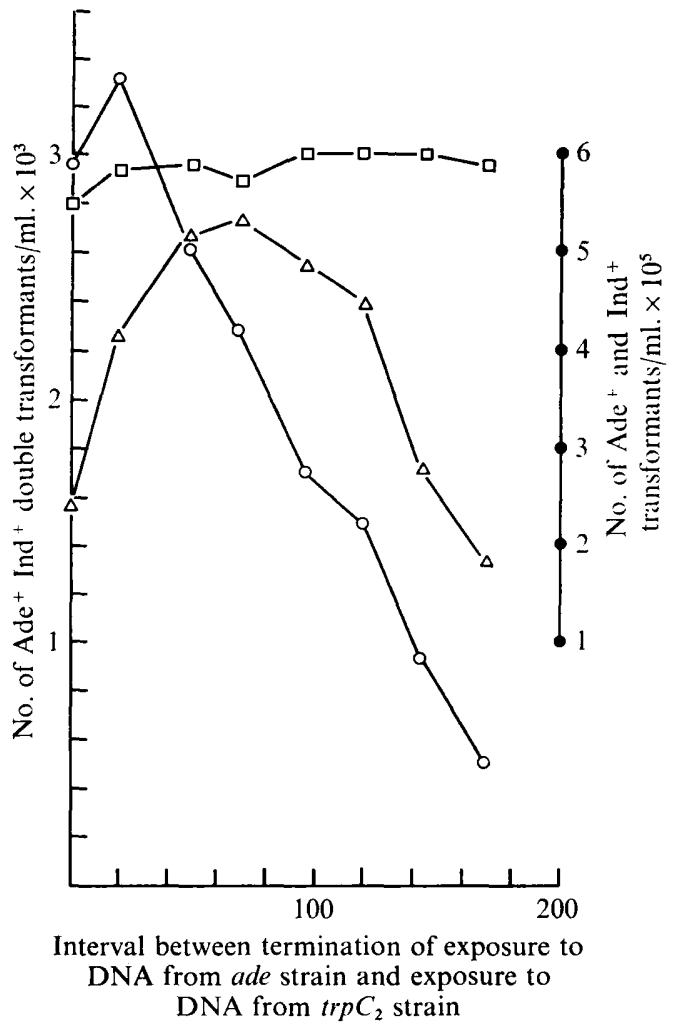

Fig. 3. Estimation of the duration of competence of individual cells. Cultures ade trpC2 grown to maximum competence (method A) were exposed to DNA from ade strain ( $0 \cdot 1 \mu \mathrm{g} . / \mathrm{ml}$.) for $20 \mathrm{~min}$. at $37^{\circ}$, treated with DNase $(50 \mu \mathrm{g}$. $/ \mathrm{ml}$.) for $5 \mathrm{~min}$., washed and resuspended in the supernatant of part of the same culture not exposed to DNA. At various times samples were exposed for $20 \mathrm{~min}$. to DNA from $\operatorname{trpC2}$ strain $\left(0 \cdot 1 \mu \mathrm{g} . / \mathrm{ml}\right.$.) at $37^{\circ}$, treated with DNase $(20 \mu \mathrm{g} . / \mathrm{ml}$.) for $5 \mathrm{~min}$. and plated. $\mathrm{O}-\mathrm{O}, \mathrm{Ade}^{+}$Ind $^{+}$double transformants; $\square-\square$, Ind ${ }^{+}$transformants; $\triangle-\triangle$, Ade $^{+}$transformants (The data are mean values of three separate experiments.)

Competent ade trpC2 cultures were exposed to unsaturated concentrations of DNA isolated from a strain requiring adenine $\left(\mathrm{Ade}^{-}\right)$only. After stopping further DNA uptake by DNase addition, the cells were washed on membrane filters and resuspended in supernatants of nontransformed competent cells. At various intervals after resuspension, samples were exposed to DNA isolated from a strain requiring indole (Ind-) only, and the number of $\mathrm{Ade}^{+} \mathrm{Ind}^{+}$double transformants was determined.

The results are shown in Fig. 3. It can be seen that the number of double transformants decreases as the interval between the exposure to DNA from the ade strain and the $\operatorname{trpC2}$ strain increases. Two hours after the first exposure $50 \%$ of the cells transformed by DNA from 
ade can still yield double transformants after exposure to DNA from $\operatorname{trp} C 2$, and even if the interval is increased to $170 \mathrm{~min}$. a small number of double transformants is still found. If it is assumed that the cells have been competent for variable lengths of time before the first type of DNA was added to the culture (which seems a reasonable assumption since the

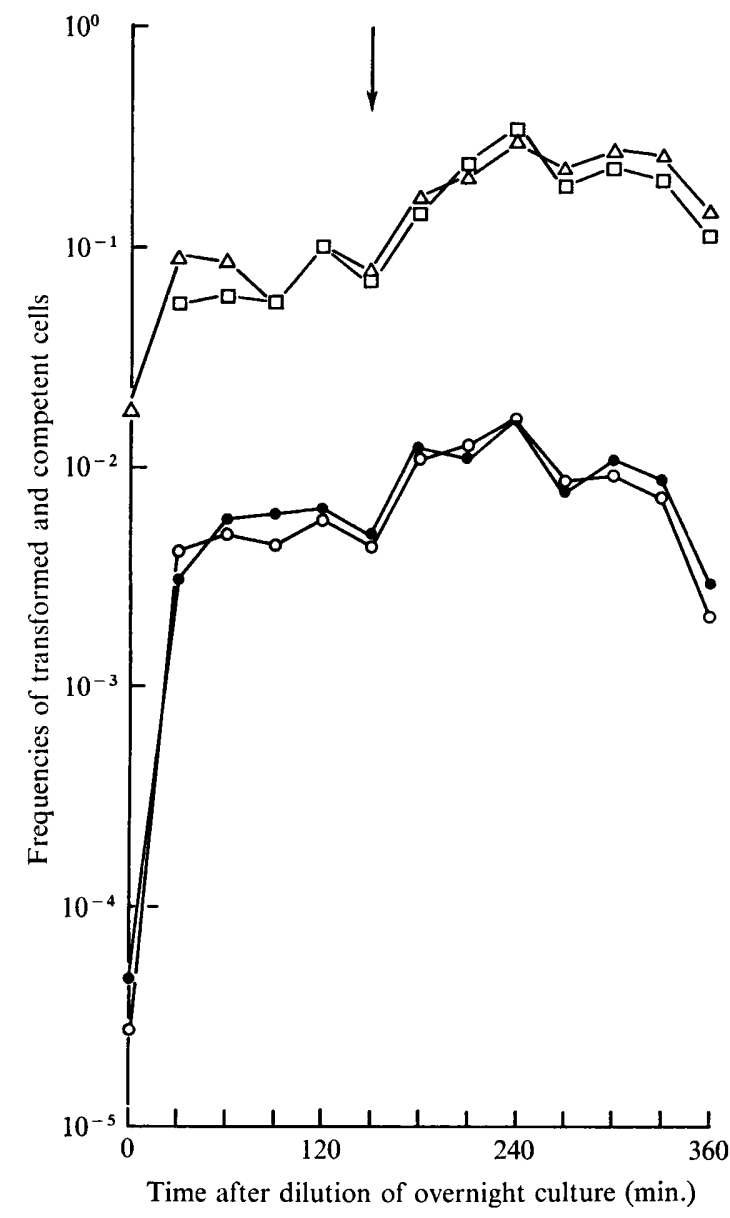

Fig. 4. Relation between transformation frequencies and the frequencies of competent cells during the competence regime (method B). At various times samples were incubated with prototrophic DNA $\left(3 \mu \mathrm{g} . / \mathrm{ml}\right.$.) and ${ }^{3} \mathrm{H}$ labelled DNA (specific activity approximately $3 \times 10^{5} \mathrm{~d} . \mathrm{p} . \mathrm{m} . / \mu \mathrm{g}$.) for $30 \mathrm{~min}$. at $37^{\circ}$, treated with DNase $(50 \mu \mathrm{g} . / \mathrm{ml}$.) for $5 \mathrm{~min}$., washed and autoradiographed. $\mathrm{Ade}^{+}$transformants; $\mathrm{O}-\mathrm{O}$, Ind ${ }^{+}$transformants; $\square-\square$, frequency of competent cells calculated from the frequencies of expected and observed $\mathrm{Ade}^{+}$Ind $^{+}$double transformants; $\triangle-\triangle$, frequency of labelled cells. (The arrow indicates the time of dilution (I/I) with fresh unsupplemented medium.)

development of competence in a culture is gradual) and that the duration of competence per individual cell is approximately constant, it may be concluded that the cells maintain their competence for approximately $3.5 \mathrm{~h}$. This follows from the observation that $170 \mathrm{~min}$. after the termination of exposure to DNA from ade strain those cells which are assumed to have become competent shortly before, can still yield double transformants by incorporating 
molecules of the second DNA added to the culture. Extrapolation of the curve representing the relation between length of the intervals and double transformants intercepts the horizontal axis at approximately $3.5 \mathrm{~h}$. This conclusion is consistent with results obtained by Nester \& Stocker (1963) and Kammen, Wojnar \& Canellakis (1966). In any case these results agree with the conclusion that during the $30 \mathrm{~min}$. interval of exposure to DNA the large majority of cells keep their competence and only a small fraction may enter the competent state.

The numbers of Ind ${ }^{+}$and double transformants increase slightly during the first $20 \mathrm{~min}$. interval between the termination of the exposure to DNA from ade and the second exposure to DNA from $\operatorname{trpC2}$, which may either be due to a decreasing competitional effect exerted by the second DNA (Kammen et al. I966), or to the washing procedure, temporarily reducing the transformability (Miller \& Landman, 1965).

The relationship between transformability and the size of the competent fraction during the competence regime. Growing cultures through the competence regime results in a gradually increasing transformability (Anagnostopoulos \& Spizizen, 196I) which may be attributed to one of the following possibilities. (I) The fraction of cells absorbing DNA from the

Table 5. Average number of grains over labelled cells in samples incubated with

${ }^{3} \mathrm{H}$ labelled DNA for $30 \mathrm{~min}$. at various times during the competence regime

Cultures were grown to maximum competence (method B), exposed to ${ }^{3} \mathbf{H}$ labelled DNA (specific activity $3 \times 10^{5} \mathrm{~d} . \mathrm{p} . \mathrm{m} . / \mu \mathrm{g}$.) for $30 \mathrm{~min}$. at various times during the competence regime, treated with DNase and plated.

\section{Duration of exposure to ${ }^{3} \mathrm{H}$ labelled DNA (min. after dilution of the overnight culture)}

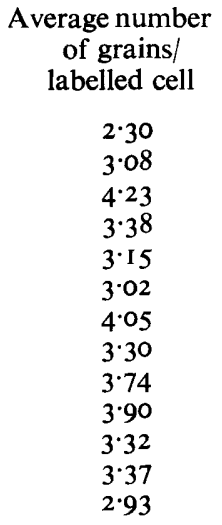

medium increases, whereas the probability that a given marker is finally expressed as a transformant, is constant during the development of competence of the cultures. (2) The fraction of cells absorbing DNA from the medium is constant, and the increase in transformability is due to increased efficiency of integrating the DNA into the recipient genome. (3) The fraction of cells absorbing DNA and the probability that a given marker is integrated and finally expressed are constant, but the amount of DNA absorbed per competent cell increases throughout the competent regime. It should be possible to discriminate between these possibilities by estimating the size of the competent fraction from the frequencies of expected and observed double transformants and autoradiography. The results of such an experiment, presented in Fig. 4, show that the size of the competent fraction during the competence regime and transformability increase proportionally.

Table 5 shows that during the competence regime the average number of grains per labelled cell does not change considerably, indicating that during the development of 
competence the capacity of competent cells to absorb DNA does not increase and that, therefore, the increased transformability during the development of competence is exclusively attributable to an increase in the size of the competent fraction. Additionally, it should be noted that there is almost complete agreement between the size of the competent fraction determined by autoradiography and the size estimated by Goodgal and Herriott's method without the modification suggested by Cahn \& Fox (1968).

\section{DISCUSSION}

A comparison between the results of the two methods used for the estimation of the size of the competent fraction necessarily needs evaluation of both methods before any definite conclusion can be drawn.

Autoradiography will lead to overestimation of the size of the competent fraction if radioactive products from the ${ }^{3} \mathrm{H}$ DNA are released by competent cells and subsequently incorporated into the genomes of noncompetent cells during DNA synthesis. Recently cells were exposed to ${ }^{3} \mathrm{H}$ DNA in the presence of an excess of non-radioactive thymidine $(80 \mu \mathrm{g}$./ $\mathrm{ml}$.) and autoradiographed. The results obtained agree with those presented here and suggest that no significant incorporation of released radioactive thymidine occurs into noncompetent cells. Moreover, if significant incorporation of released radioactive products had occurred, one would expect to observe a large deviation from the Poisson distribution toward lower grain numbers. Autoradiography would also overestimate the size of the competent fraction if noncompetent cells absorb DNA which is resistent to DNase. However, this possibility is not very likely since evidence has been presented that only competent cells absorb DNA (Singh \& Pitale, 1968).

As has been pointed out by Nester \& Stocker (1963) the double marker method for calculating the size of the competent fraction will only give reliable results if competent cells are uninuclear. If competent cells are multinuclear and if integration occurs in more than one nucleus, only part of the potential double transformants will be scored as real doubles, resulting in an overestimation of the size of the competent fraction. Results recently obtained by Bresler, Kreneva \& Kushev (1968) from a clonal analysis of Bacillus subtilis transformants, indicate that competent cells are uninuclear. More direct evidence for the uninuclearity of the majority of competent cells of B. subtilis was obtained by Singh \& Pitale (1968).

As has been pointed out by Cahn \& Fox (1968) a further factor contributing to the overestimation of the size of the competent fraction is the single stranded level of integration of the donor DNA, for which substantial evidence is available (Bodmer \& Ganesan, 1964; Venema et al. 1965; Vestri et al. 1966; Dubnau \& Davidoff-Abelson, 1971). Even if competent cells are uninuclear, the size of the competent fraction will be overestimated by a factor of two if either strand of the DNA duplex is active in individual cells. Surprisingly, however, the discrepancy between the double marker and the autoradiographic method is small. These results are at variance with those of Javor \& Tomasz (1968) as well as those of Somma \& Polsinelli (1970), which have reported significantly higher values obtained by autoradiography.

Although Riva \& Polsinelli (I968) showed that the size of the competent fractions determined with Goodgal and Herriott's method are very similar to transfection frequencies, the significance of this similarity is not entirely clear as there is evidence (Epstein, 1968; Oostindiër-Braaksma \& Epstein, 1970) that competence for transformation and transfection may not be the same. Several explanations suggest themselves for the observation described here that the size of the competent fraction determined by autoradiography is approximately 
in agreement with that computed by the double marker method without the correction suggested by Cahn \& Fox (1968) for random strand integration.

(I) Individual competent cells integrate the transforming strands predominantly in one specific strand of their genome. Although for the competent population as a whole, random strand integration has been reported for Bacillus subtilis (Chilton, 1967; Rudner, Karkas \& Chargaff, 1968), Haemophilus influenzae (Goodgal \& Notani, 1968) and Diplococcus pneumoniae (Peterson \& Guild, I968), this does not necessarily exclude the possibility that cells which have absorbed a multiplicity of duplexes preferably integrate strands of the same polarity. (2) There is a high degree of heteroduplex repair with the donor strand as template.

In a study of molecular heterozygotic repair of transformed cells, Bresler et al. (I968) reported that correction of molecular heterozygotes occurs in recombinant cells and amounts to $50 \%$ for the SB $25 \operatorname{trpC2}$ marker. Bresler's method does not permit us to conclude that the repair system uses preferably the donor strand as template.

Since, at present, no information is available with regard to the possibility that in individual cells only strands of the same polarity are integrated into the recipient genome, no definite conclusion can be drawn. Preliminary results from clonal analysis of transformed cells indicate that potential double transformants (cells which have incorporated the two markers selected for) give rise to actual double transformants with a high probability.

As was to be expected the calculated size of the competent fraction is found to be independent of DNA concentration or the time of exposure to DNA, which follows from the expression $(A \times B) / C$ from which the competent fraction is calculated (Goodgal \& Herriott, I96I). If the frequencies of the two types of single transformants increase by a factor $p$ and $q$ respectively, the size of the competent fraction will be $(p A \times q B) / p q C$.

At variance with the finding that the size of the competent fraction determined with Goodgal and Herriott's method is independent from the DNA concentration, Somma \& Polsinelli (1970) have reported a strong increase in the frequency of labelled cells if exposed to higher concentrations of DNA, whereas the grain numbers over labelled cells increased only slightly.

The grain number distributions over the labelled cells (Fig. 2) are somewhat broader than predicted from the Poisson distribution. In addition to the probability of disintegration of the tritium atoms, which follows a true Poisson distribution, there are a number of factors which may affect this distribution: (i) the variation in thymine content in a particular amount of DNA incorporated from the medium; (ii) the probability of radioactive disintegration to produce a latent image; (iii) the probability of changing a latent image into a visible grain during development.

In spite of these factors, all of which would tend to broaden a true Poisson distribution, the distributions obtained resemble a Poisson distribution closely, indicating that the possible contribution of these factors is small and that there is no significant heterogeneity in the DNA absorption capacity of the individual competent cell. These results agree with those of Bresler, Mosevitskii \& Timkovskii (I963).

The results obtained with regard to the relatively long duration of the competent state of Bacillus subtilis cells agree with those of Kammen et al. (1966) and Nester (1964), but are at variance with those obtained in other transformation systems (Hotchkiss, 1954) and may, perhaps, be attributed to the generally noted biochemical latency of competent $B$. subtilis cells (Nester \& Stocker, 1963; Nester, 1964; Bodmer, I965; Farmer \& Rothman, 1965).

The finding that transformability and the size of the competent fraction at different stages during the development of competence are correlated, confirms the results of Somma \& Polsinelli (1970). However, their data show that the degree of transformability was more 
closely correlated with the size of the competent fraction determined with Goodgal and Herriott's method than with the frequency of labelled cells. The observation that individual competent cells incorporate equal amounts of DNA from the medium, although presumably having been for various lengths of time in their competent state, indicates that as soon as competence has developed the cell is able to absorb the maximally possible amount of DNA imposed by the concentration of DNA and the time of exposure to DNA. More specifically, the possibility that the number of receptor sites increases gradually or that the receptor sites become functional as a function of time, is not easily reconciled with the results obtained.

Finally, the observation, that the efficiency of integration is not subject to changes during the development of competence in a given competence regime, poses the interesting question whether this is due to the existence of a fully functional integration system before the competent state is obtained, or to an integration system developing simultaneously with and as an integral part of competence.

The authors are indebted to Professor W. J. Feenstra for critical reading of the manuscript and to $\mathrm{Mr}$ A. Sÿbers for his co-operation in part of the experiments. This investigation was supported by a grant from the Netherlands Organization for the Advancement of Pure Research (Z.W.O.).

\section{REFERENCES}

Anagnostopoulos, C. \& SpIzizen, J. (I961). Requirements for transformation in Bacillus subtilis. Journal of Bacteriology 81, 74I-746.

BODMER, W. F. (1965). Recombination and integration in Bacillus subtilis transformation: involvement of DNA synthesis. Journal of Molecular Biology 14, 534-557.

BODMER, W. F. \& GANESAN, A. T. (1964). Biochemical and genetic studies of integration and recombination in Bacillus subtilis transformation. Genetics 50, 717-738.

BraX, G. A. (1960). A simple efficient liquid scintillator for counting aqueous solutions in a liquid scintillation counter. Annals of Biochemistry I, 279-285.

Bresler, S. E., Kreneva, R. A. \& Kushev, V. V. (1968). Correction of molecular heterozygotes in the course of transformation. Molecular and General Genetics ro2, 257-268.

Bresler, S. E., Mosevitskir, M. I. \& Timkovskir, A. L. (1963). The irregular penetration of DNA into cells, accompanying bacterial transformation. Doklady Akademii Nauk SSSR 149, 721-724.

Burton, K. (1956). A study of the conditions and mechanism of the diphenylamine reaction for the colorimetric estimation of deoxyribonycleic acid. Biochemical Journal 62, 315-323.

CAHN, F. H. \& Fox, M. S. (1968). Fractionation of transformable bacteria from competent cultures of Bacillus subtilis on renografin gradients. Journal of Bacteriology 95, 867-875.

ChILton, M. D. (1967). Transforming activity in both complementary strands of Bacillus subtilis DNA. Science, New York 157, 817-819.

Dubnau, D. \& Davidoff-Abelson, R. (I97I). Fate of transforming DNA following uptake by competent Bacillus subtilis. I. Formation and properties of the donor-recipient complex. Journal of Molecular Biology 56, 209-221.

EPSTEIN, H. T. (1968). Factors affecting bacterial competence for transfection and transfection enhancement. Bacteriological Reviews 32, 313-319.

FARMER, J. L. \& Rothman, F. (1965). Transformable thymine requiring mutant of Bacillus subtilis. Journal of Bacteriology 89, 262-263.

Goodgal, S. H. \& Herriott, R. M. (I96I). Studies on transformation of Haemophilus influenzae. I. Competence. Journal of General Physiology 44, 120I-1227.

Goodgal, S. H. \& NotANI, N. (1968). Evidence that either strand of DNA can transform. Journal of Molecular Biology 35, 449-453.

HAdden, C. \& Nester, E. W. (1968). Purification of competent cells in the Bacillus subtilis transformation systems. Journal of Bacteriology 95, 876-885. 
HotchKIss, R. D. (1954). Cyclical behaviour in pneumococcal growth and transformability occasioned by environmental changes. Proceedings of the National Academy of Sciences of the United States of America 40, 49-55.

JAVOR, G. T. \& TOMAsz, H. (1968). An autoradiographic study of genetic transformation. Proceedings of the National Academy of Sciences of the United States of America 60, $1216-1222$.

Kammen, H., Wojnar, R. \& Canellakis, E. (1966). Transformation in Bacillus subtilis. II. The development and maintenance of the competent state. Biochimica et biophysica acta 123, 56-65.

MilleR, I. L. \& LANDMAN, O. E. (1966). On the mode of entry of transforming DNA into Bacillus subtilis. In|The Physiology of Gene and Mutation Expression. Symposium on the Mutational Process, pp. I87194. Edited by M Kohoutova \& J. Hubacek. Prague: Academia.

Nester, E. W. (1964). Penicillin resistance of competent cells in deoxyribonucleic acid transformation of Bacillus subtilis. Journal of Bacteriology 87, 867-875.

Nester, E. W. \& Stocker, B. A. D. (1963). Biosynthetic latency in early stages of deoxyribonucleic acid transformation in Bacillus subtilis. Journal of Bacteriology 86, 785-796.

Oostindiër-BRAAKSMA, F. Y. \& EPSTEIN, H. T. (1970). DNA fixation and development of transformability and transfectability in Bacillus subtilis. Molecular and General Genetics ro8, 23-27.

Peterson, J. M. \& Guild, W. R. (1968). Fractionated strands of bacterial deoxyribonucleic acid. III. Transformation efficiencies and rates of phenotypic expression. Journal of Bacteriology 96, I99 I-I 996.

Riva, S. \& Polsinelli, M. (I968). Relationship between competence for transfection and for transformation. Journal of Virology 2, 587-593.

Rogers, A. W. (1967). Techniques of Autoradiography, pp. 246-250. Amsterdam: Elseviers Publishing Company.

RudNer, R., Karkas, J. D. \& ChargafF, E. (1968). Separation of Bacillus subtilis DNA into complementary strands. I. Biological properties. Proceedings of the National Academy of Sciences of the United States of America 60, 630-635.

Singh, R. N. \& Pitale, M. P. (1968). Competence and deoxyribonucleic acid uptake in Bacillus subtilis. Journal of Bacteriology 95, 864-866.

Somma, S. \& Polsinelli, M. (1970). Quantitative autoradiographic study of competence and deoxyribonucleic acid incorporation in Bacillus subtilis. Journal of Bacteriology ror, 85I-855.

SPIZIZEN, J. (1958). Transformation of biochemically deficient strains of Bacillus subtilis by deoxyribonucleate. Proceedings of the National Academy of Sciences of the United States of America 44, 1072-1078.

Venema, G., Pritchard, R. H. \& Venema-Schröder, T. (1965). Fate of transforming deoxyribonucleic acid in Bacillus subtilis. Journal of Bacteriology 89, I250-1255.

Vestri, R., Felicetti, L. \& Lostia, O. (1966). Transformation by hybrid DNA in Bacillus subtilis. Nature, London 209, I1 54-1 I 55.

WILson, G. A. \& BotT, K. F. (1968). Nutritional factors influencing the development of competence in the Bacillus subtilis transformation system. Journal of Bacteriology 95, I439-1449. 